\title{
The Measurement of Analysts' Earnings Forecast Uncertainty
}

\author{
Chun Hu \\ Management School, Jinan University, Guangzhou, China \\ Email: huchun0928@foxmail.com
}

Received 3 March 2015; accepted 3 April 2015; published 17 April 2015

Copyright (C) 2015 by author and Scientific Research Publishing Inc. This work is licensed under the Creative Commons Attribution International License (CC BY). http://creativecommons.org/licenses/by/4.0/

cC) (i) Open Access

\begin{abstract}
Analysts' earnings forecast began in the early 20th century in America, researchers and investors are especially interested in estimating uncertainty about future earnings, because it reveals important characteristics of the firm's information prior to the release of accounting results. Since uncertainty is inherently unobservable, evaluating its estimates poses challenging methodological problems. As a result, researchers have put forward alternative proxies for earnings forecast uncertainty. Here, we will review the measurement used in the study of foreign scholars of analysts' earnings forecast uncertainty, and make a comparison among various methods. Considering the background of information, prediction model and analysts cannot be expected to know the cause of the situation, GARCH as an ex ante measure, will be one of the most accurately measures of uncertainty. Studying the methods of analysts' earnings forecast uncertainty will be conducive to market participants to understand the characteristics of analysts' earnings forecast, so as to make more rational decisions.
\end{abstract}

\section{Keywords}

Analysts' Earnings Forecast, Measurement, Uncertainty

\section{Introduction}

In the current capital market, due to the separation of corporate ownership and management rights, information asymmetry has caused very serious problem, leading to the securities investment with high uncertainty. In order to get more relevant information, investors become increasingly demand for information disclosure. In the past, the information disclosed by the company mainly focused on the historical information, and the financial and non-financial information. With the rapid development of the securities market, great changes have taken place, creditors, investors and other market participants are aware of the important of future information. Therefore, 
people begin to focus on predicted information, especially for the earnings forecast. The mainly object of earnings forecast is to predict the financial condition of a certain period in the future. There are two main sources of earnings forecast information, one is the information released by management of the company, the other is the information released by analysts. Management as the internal interests of shareholder, may focus on cost, interests and not willing to disclose the information of prediction earnings. Therefore, most investors are difficult to get the earnings forecasts made by management. Because of the analysts' professional and information advantages, their earnings forecast information will be propitious to reduce information asymmetry, reduce the cost of capital, improve the efficiency of the overall market, and help investors make excellent investment decisions. Analysts' earnings forecasts is not only making evaluation but also providing investment advice to customers.

Generally speaking, analysts have the professional ability of analysis and information advantages (including public information and private information), their earnings forecast is unbiased. However, a number of studies have found that analysts' earnings forecast has obvious tendency. In fact, the temptation of interests or stress often leads to the analysts lose independence. The earnings forecast made by analysts is often not objective, even intentionally mislead investors. That is to say, analysts' earnings forecast is biased. Therefore, the measurement of analysts' earnings forecast uncertainty will help market participants understand the characteristics of analysts' earnings forecast, so as to make better use of analysts' earnings forecast information to make investment decisions.

Analysts' earnings forecast uncertainty, refers to the differences between the predicted and actual earnings. Dating back to 20th Century, American had a large number of scholars committed to analysts' earnings forecast uncertainty. Compared to a large number of foreign literatures research analysts' earnings forecast, the domestic research in this area started too late. This paper reviewed the measurement of uncertainty, and then focuses on three different measurements of earnings forecast uncertainty: forecast dispersion, BKLS, and GRACH. And then discusses in detail the conditions and limitations of using a variety of methods, analysis and make a comparison of various measurements. This study will benefit for China to learn advanced foreign research methods and provide the method of in-depth understanding of analysts' earnings forecast.

\section{Measurement of Earnings' Forecast Uncertainty}

\subsection{Forecast Dispersion}

Due to the practical availability of point forecasts, the dispersion of earnings forecast is widely used to measure the uncertainty of future earnings forecast (Baginski [1]; Diether [2]; Clement [3]; Yeung [4]). Daley (1988), Imhoff and Lobo (1992) [5] found that the earnings forecast dispersion may reflect the uncertainty of the future cash flow. They hold the view that dispersion is a reflection of the relevant part of the financial report of the company and the price of uncertainty. Barron and Stuerke (1998) [6] found that there is a positive correlation between the earnings forecast dispersion and release of information demand, which shows that the analysts' earnings forecast dispersion is a good method measuring the company's earnings forecast uncertainty. Zhang (2006) [7] used forecast dispersion as a substitution variable for uncertainty information, he believed that the dispersion including two aspects of uncertainty: the corporation and the lack of information.

Researchers also doubt about the appropriateness of the dispersion measuring analysts' earnings forecast uncertainty. Using 1983 to 2000 American listing corporation data, Diether (2002) found that analyst earnings forecasts uncertainty are related to the future earnings. He found that the average income of larger differences portfolio was lower than smaller differences portfolio. But Deither's conclusion is controversial, there are two main aspects: Firstly, not all investors make decisions according to analysts' earnings forecasts, analysts forecast difference just shows investors' belief difference, not representative of the actual judgment of investors; Secondly, analysts' earnings forecast is also affected by the other factors. Abarbanell (1995) [8] and Johnson (2004) [9] believed that in addition to the dispersion of prediction, the other features will also affect the accuracy of forecast uncertainty, for example, public information and the number of analysts predict. In addition, Barron (2009) [10] put forward that the change of the dispersion does not mean the changes of uncertainty, but the change of information asymmetry. It was different from what Diether (2002) proposed. He thought that the dispersion can be used to measure the levels of uncertainty. Bomberger (1996) [11], Giordani and Soderlind (2003) [12] also thought that, dispersion as a measurement of uncertainty, was still not a theoretical basis. Brown, Han (1992) [13] and Stickel (1996) found that all records for the earnings forecast dispersion were artificially increased. 
Based on the above analysis, dispersion as a measure of earnings forecast uncertainty, has many advantages. Dispersion reflects the company's future cash flows or information demand uncertainty, and can be calculated using existing data before real earnings announcement, and also easy to calculate. It's a good method measuring earnings forecast uncertainty if only have analysts' earnings forecast data. But dispersion is not enough to measure the earnings forecast uncertainty. In fact, the dispersion represents only an element of uncertainty, the uncertainty of earnings forecast made by analysts will be affected by other unpredictable uncertainties, for example $V_{t h}=e^{2} t_{h}+d_{t h}{ }^{1}$. That is to say, the difference between earnings forecast and forecast dispersion is $e^{2}$ th $e^{2}$ th is mainly determined by the unexpected events. When the observation period is long, unexpected events are more likely to happen, then the difference between the forecast dispersion and uncertainty will increase. This suggests that the relationship between the forecast dispersion and the forecast uncertainty is affected by the unexpected events. In the relatively peaceful years, which the probability of unexpected events occurrence is low, the dispersion is a good measurement of forecast uncertainty. But in the years with high probability of unexpected events, the dispersion should not be completely replaced the uncertainty. Based on the above analysis, researchers and investors should be careful when using dispersion as the uncertainty measurement.

\subsection{BKLS Uncertainty}

As mentioned above, the earnings forecast uncertainty is composed of two aspects, thus creating an alternative measure of earnings forecast uncertainty. The method proposed by Barron (1998) [14], assuming that the analysts can get the future earnings related to public and private information, he put forward the actual squared error in the mean forecast as a proxy for the expected squared error (BKLS Uncertainty). BKLS uncertainty evaluation method identify the uncertainty is composed of two parts, which is widely used in the study of analyst earnings forecast information environment (Barron [15]; Liang, 2003 [16]; Botosan and Stanford [17]; Doukas [18]; Yeung [4]).

It should be noted that, only after the real earnings information announcement, the forecast errors are known to analysts. So the BKLS uncertainty measurement can only be used as ex post uncertainty measurement. At the same time, BKLS uncertainty measurement is easy to be affected by unexpected events, such as 911, bankruptcy and reorganization. Sheng and Thevenot (2012) [19] listed the predicted changes in AMR earnings after the 911. Because of the impact of the 911, AMR's revenue suffered severe decline, so as to the BKLS uncertainty was increased tremendously. As a result, the earnings forecast uncertainty calculated by BKLS was 350 times higher than usual. In addition, this method assumes that the real surplus is exogenous, and is not affected by the analyst forecasts. However, this assumption is difficult to control in practice. This is because there are a large number of studies indicated that the managers manipulate the surplus to reach or exceeded analysts' forecasts (Degeorge [20]; Abarbanell and Lehavy [21]). Degeorge (1999) [20] showed that managers manipulate surplus reached or exceeded analysts' forecast. Abarbanell and Lehavy (2003) [21] recognised the asymmetric relationship between the non expected revenue and forecast error, that suggested the company's decision seriously affected the analyst's earnings forecast.

Thus, BKLS uncertainty measurement accurately identify the earnings forecast uncertainty is composed of two parts. It has advantage over forecast dispersion that forecast dispersion will underestimate the forecast uncertainty. At the same time, BKLS uncertainty measurement takes events cannot be predicted by analysts of uncertainty into consideration. However, BKLS uncertainty measurement can be used only as ex post measurement, and cannot provides reference information to market participants before the real earnings announcement. And then, it is impracticable that the actual earning is exogenous. What's more, BKLS measurement is easily affected by unexpected events. Based on long-term perspective, is not suitable for measuring uncertainty. So the BKLS uncertainty measurement also has some limitations.

\subsection{GARCH}

Bollerslev (1986) [22] put forward a new method to measure the earnings forecast uncertainty, the method was first proposed by Engle's (1982) [23] Autoregressive Conditional Heteroscedasticity (ARCH) model. These models can be used to estimate volatility conditional on historical data and are therefore suitable for our purpose. The technique is now a standard approach for modeling different types of uncertainty in economics and finance.

\footnotetext{
${ }^{1} V_{t h}=e_{t h}^{2}+d_{t h}, V_{t h}$ is the earnings forecast uncertainty. $e_{t h}=y_{t}-\mu_{t h}, y_{t}$ is the actual earnings, $e_{t h}$ is the forecast error. See Barron (1998) Dispersion in analysts' earnings forecasts as a measure of uncertainty.
} 
The GARCH model assumes that the volatility of mean forecast errors depends on past forecast errors and lagged earnings forecast uncertainty. Specifically, the method uses historical mean forecast errors to provide an estimate of the variance of mean forecast errors for the current period.

Because measuring uncertainty is mainly to provide valuable information to market participants before the real earnings information release, therefore it must rely on the information that analysts available at the time of making earnings forecasts. Assuming that the historical information is available when analysts making earnings forecast, the authors propose the Autoregressive Conditional Heteroscedasticity (ARCH) model to estimate the variance of the prediction error. That is to say, $V_{t h}=\hat{\sigma}_{t h}^{2}+d_{t h}^{2}$ Sheng and Thevenot (2012) [19] used the 1984-2007 I/B/E/S data empirical to study the performance of this new method. They hold that use dispersion to measure the uncertainty will underestimate the uncertainty. In the period of extreme event happened, using the BKLS method to measure the uncertainty will be higher than the other two methods, because BKLS uncertainty measurement is greatly affected by emergencies. In contrast, when facing with the above two situations, GARCH can properly measure the analysts' earnings forecast uncertainty. The empirical results also show that in the long-term perspective, using the method of GARCH is more positive than using other two methods to measure the earnings forecast and earnings discrepancy.

In summary, the GARCH method not only takes into consideration the analysts' forecast model caused by background information or uncertainty, but also takes into account the incident analyst cannot be predicted, so it can avoid the disadvantage of dispersion. Compared to the existing proxies for uncertainty in the literature, the proposed measure has some obvious advantages: 1 ) it provides a measure of uncertainty that is conditional on observing forecasts and hence, can be estimated in practice; 2 ) it is based on information available to analysts at the time they make their forecasts and gives an ex ante measure of uncertainty, thus alleviating some of the limitations associated with BKLS uncertainty; and 3) it captures the uncertainty arising from both analysts' common and private information and therefore avoids the problems of using dispersion alone as a proxy for uncertainty. This procedure provides estimated overall uncertainty that can be used in settings where other measures cannot, such as when firms' operations are affected by unanticipated events, bankruptcy and large restructuring charges and when the construct of interest is the change in uncertainty. The new measurement is easy to implement, since many widely used statistical software packages, such as Stata, Eviews and SAS, contain preprogrammed routines for the estimation of the GARCH models. For the future direction of development of this method, we may discuss how much the analysts' earnings forecast uncertainty affect the public. Another worthwhile extension is to estimate the expected squared error in the mean forecast by using the technique suggested in this paper and develop empirical proxies for other theoretical constructs, such as consensus and precision of information in earnings forecasts.

\section{Conclusions}

In this paper, according to introduce three measures of earnings forecast uncertainty, we serve mainly to provide market participants for methods of measuring earnings forecast uncertainty. Measuring earnings forecast uncertainty will not only be conducive to market participants understand and excavate the characteristics of analysts' earnings forecasts, but also offer researchers more alternative variables for earnings forecast uncertainty, so as to use analysts' earnings forecast information more reasonably.

Overall, the foreign studies on analysts' earnings forecasts have been relatively mature. In contrast, the research in our country is too late. Looking back the domestic research, although in recent years there has been many researches concern the behavior of analysts, but they all based on qualitative analysis, and few of them make an empirical study on the use of analysts' forecasts. The research on analysts' earnings forecast uncertainty measure is little. With the development of Chinese securities market, analysts industry gradually standardized, the establishment of the database provide for scholars great opportunities engaged in analysts' earnings forecasts research. Draw lessons from foreign mature research on analyst behavior and put forward new model for China market environment, will contribute for us to evaluate the analyst in the capital market objectively, and to understand the characteristics of analyst forecasts (including accuracy, error correction behavior, etc.), and to help investors better understand and use the analyst research report. What's more, it also provides the basis for regulators to make policy.

\footnotetext{
${ }^{2} V_{t h}=\hat{\sigma}_{t h}^{2}+d_{t h}, \hat{\sigma}_{t h}^{2}$, is the estimated variance of the prediction error, it can be calculated by the historical average forecast error.
} 
This paper summarizes the measurement of analysts' earnings forecast uncertainty, it enriches researches of the analysts' earnings forecast and analysts behavior. Studying the methods of analysts' earnings forecast uncertainty will be conducive to market participants to understand the characteristics of analysts' earnings forecast, so as to make more rational decisions. The limitation of this paper is, it only introduces three methods of earnings forecast uncertainty, but not put the three kinds of methods to use in practice, the applicability of various methods in China needs to be further verified.

\section{References}

[1] Baginski, S.P., Conrad, E.J. and Hassell, J.M. (1993) The Effects of Management Forecast Precision on Equity Pricing and on the Assessment of Earnings Uncertainty. Accounting Review, 68, 913-927.

[2] Diether, K.B., Malloy, C.J. and Scherbina, A. (2002) Differences of Opinion and the Cross Section of Stock Returns. The Journal of Finance, 57, 2113-2141. http://dx.doi.org/10.1111/0022-1082.00490

[3] Clement, M., Frankel, R. and Miller, J. (2003) Confirming Management Earnings Forecasts, Earnings Uncertainty, and Stock Returns. Journal of Accounting Research, 41, 653-679. http://dx.doi.org/10.1111/1475-679X.00119

[4] Yeung, P.E. (2009) Uncertainty and Expectation Revisions after Earnings Announcements. Contemporary Accounting Research, 26, 273-301. http://dx.doi.org/10.1506/car.26.1.10

[5] Imhoff Jr., E.A. and Lobo, G.J. (1992) The Effect of Ex Ante Earnings Uncertainty on Earnings Response Coefficients. Accounting Review, 67, 427-439.

[6] Barron, O.E. and Stuerke, P.S. (1998) Dispersion in Analysts' Earnings Forecasts as a Measure of Uncertainty. Journal of Accounting, Auditing \& Finance, 13, 245-270.

[7] Zhang, X. (2006) Information Uncertainty and Stock Returns. The Journal of Finance, 61, 105-137. http://dx.doi.org/10.1111/j.1540-6261.2006.00831.x

[8] Abarbanell, J.S., Lanen, W.N. and Verrecchia, R.E. (1995) Analysts’ Forecasts as Proxies for Investor Beliefs in Empirical Research. Journal of Accounting and Economics, 20, 31-60. http://dx.doi.org/10.1016/0165-4101(94)00392-I

[9] Johnson, T.C. (2004) Forecast Dispersion and the Cross Section of Expected Returns. The Journal of Finance, 59, 1957-1978. http://dx.doi.org/10.1111/j.1540-6261.2004.00688.X

[10] Barron, O.E., Stanford, M.H. and Yu, Y. (2009) Further Evidence on the Relation between Analysts’ Forecast Dispersion and Stock Returns. Contemporary Accounting Research, 26, 329-357. http://dx.doi.org/10.1506/car.26.2.1

[11] Bomberger, W.A. (1996) Disagreement as a Measure of Uncertainty. Journal of Money, Credit and Banking, 28, 381392. http://dx.doi.org/10.2307/2077981

[12] Giordani, P. and Söderlind, P. (2003) Inflation Forecast Uncertainty. European Economic Review, 47, 1037-1059. http://dx.doi.org/10.1016/S0014-2921(02)00236-2

[13] Brown, L.D. and Han, J.C.Y. (1992) The Impact of Annual Earnings Announcements on Convergence of Beliefs. Accounting Review, 67, 862-875.

[14] Barron, O.E. and Stuerke, P.S. (1998) Dispersion in Analysts' Earnings Forecasts as a Measure of Uncertainty. Journal of Accounting, Auditing \& Finance, 13, 245-270.

[15] Barron, O.E., Byard, D., Kile, C., et al. (2002) High-Technology Intangibles and Analysts’ Forecasts. Journal of Accounting Research, 40, 289-312. http://dx.doi.org/10.1111/1475-679X.00048

[16] Liang, L. (2003) Post-Earnings Announcement Drift and Market Participants’ Information Processing Biases. Review of Accounting Studies, 8, 321-345. http://dx.doi.org/10.1023/A:1024477831740

[17] Botosan, C.A. and Stanford, M. (2005) Managers’ Motives to Withhold Segment Disclosures and the Effect of SFAS No. 131 on Analysts’ Information Environment. The Accounting Review, 80, 751-772. http://dx.doi.org/10.2308/accr.2005.80.3.751

[18] Doukas, J.A., Kim, C.F. and Pantzalis, C. (2006) Divergence of Opinion and Equity Returns. Journal of Financial and Quantitative Analysis, 41, 573-606. http://dx.doi.org/10.1017/S0022109000002544

[19] Sheng, X. and Thevenot, M. (2012) A New Measure of Earnings Forecast Uncertainty. Journal of Accounting and Economics, 53, 21-33. http://dx.doi.org/10.1016/j.jacceco.2011.11.001

[20] Degeorge, F., Patel, J. and Zeckhauser, R. (1999) Earnings Management to Exceed Thresholds. The Journal of Business, 72, 1-33. http://dx.doi.org/10.1086/209601

[21] Abarbanell, J. and Lehavy, R. (2003) Biased Forecasts or Biased Earnings? The Role of Reported Earnings in Explaining Apparent Bias and Over/Underreaction in Analysts’ Earnings Forecasts. Journal of Accounting and Economics, 36, 105-146. http://dx.doi.org/10.1016/j.jacceco.2003.11.001 
[22] Bollerslev, T. (1986) Generalized Autoregressive Conditional Heteroskedasticity. Journal of Econometrics, 31, 307327. http://dx.doi.org/10.1016/0304-4076(86)90063-1

[23] Engle, R.F. (1982) Autoregressive Conditional Heteroscedasticity with Estimates of the Variance of United Kingdom Inflation. Econometrica: Journal of the Econometric Society, 50, 987-1007. http://dx.doi.org/10.2307/1912773 